\title{
Spectrum of ocular manifestations and visual outcomes of neurosyphilis among 53 patients
}

\author{
Espectro de manifestações oculares e prognóstico visual da neurossífilis em 53 pacientes \\ Tatiana Vaz Leite PINTO', Antônio Pereira GOMES NETO², Matheus Nader CUNHA², Letícia Moreira \\ BERNARDINO², Paulo Pereira CHRISTO1,3
}

\begin{abstract}
Background: In the era of the re-emergence of syphilis, ocular syphilis has gained attention because its prevalence has increased and it can cause blindness and disability. Objectives: To investigate the clinical presentation and prognosis of ocular syphilis. Methods: Prospective study on 53 patients (90 eyes) with ocular syphilis diagnosed at the Santa Casa of Belo Horizonte, Brazil. The diagnosis was based on clinical manifestations of the disease and on serological markers (positive serum treponemal and non-treponemal tests or two positive treponemal tests). Results: Thirty-five eyes (66\%) were from men and the mean age was $45.3 \pm 12.0$ years. HIV coinfection was confirmed in 10 patients (18.9\%). Forty-four (84.9\%) had VDRL titers $\geq 1: 32$. Bilateral ocular involvement occurred in 68\%. Optic neuritis was diagnosed in $51.7 \%$ of the eyes and uveitis in $48.2 \%$. Regarding visual acuity, the median baseline logarithm of the minimum angle of resolution (logMAR) was 1 (20/200 Snellen), while after antibiotic therapy, the median was 0.2 (20/30 Snellen). Poor visual acuity after treatment, defined as the bestcorrected visual acuity (BCVA; logMAR 1; 20/200 Snellen) or worse, was associated with severe BCVA at presentation (below logMAR 1.3; $20 / 400$ Snellen) $(p=0.001)$ and age over 50 years $(p=0.001)$. Conclusions: This study confirms the wide spectrum of clinical manifestations of ocular syphilis. The most frequent form was optic neuritis, an important differential diagnosis from other causes of inflammatory neuritis. Early diagnosis is essential, given that this is a treatable condition with excellent visual recovery in most cases.
\end{abstract}

Keywords: Ocular syphilis; Neurosyphilis; Ocular manifestations; Optic neuritis; Visual outcome.

RESUMO

Introdução: Na era do ressurgimento da sífilis, a sífilis ocular ganhou grande atenção, pois sua prevalência está aumentando e ela pode causar cegueira e incapacidades. Objetivos: Investigar a apresentação clínica e o prognóstico da sífilis ocular. Métodos: Estudo prospectivo com 53 pacientes (90 olhos) com sífilis ocular diagnosticados na Santa Casa de Belo Horizonte, Brasil. Os diagnósticos foram feitos com base em manifestações clínicas da doença e marcadores sorológicos (um teste treponêmico e outro não treponêmico positivos ou dois testes treponêmicos positivos). Resultados: Trinta e cinco olhos (66\%) eram de homens e a idade média foi de 45,3 $\pm 12,0$ anos. A co-infecção pelo HIV foi confirmada em 10 (18,9\%) pacientes. O envolvimento ocular bilateral ocorreu em 68\%. Neurite óptica foi diagnosticada em 51,7\% dos olhos e uveíte, em 48,2\%. A mediana do logaritmo do ângulo mínimo de resolução (logMAR) foi 1 (20/200 Snellen), enquanto que após a antibioticoterapia, a mediana foi 0,2 (20/30 Snellen). A baixa acuidade visual após o tratamento, definido como logMAR 1 (20/200 Snellen) ou pior, foi associada a: gravidade da acuidade visual na apresentação da doença (abaixo de logMAR 1.3-20/400 Snellen) ( $p=0,001$ ) e idade acima de 50 anos $(p=0,001)$. Conclusões: 0 estudo confirmou o amplo espectro de manifestações clínicas da sífilis ocular. A forma mais frequente foi a neurite óptica, um diagnóstico diferencial importante das neurites inflamatórias. O diagnóstico precoce é essencial, é uma condição tratável e com excelente recuperação, na maior parte dos casos

Palavras-chave: Sífilis ocular; Neurossífilis; Manifestações oculares; Neurite óptica.

\footnotetext{
IInstituto de Ensino e Pesquisa da Santa Casa de Belo Horizonte, Belo Horizonte MG, Brazil.

${ }^{2}$ Santa Casa de Misericórdia de Belo Horizonte, Departamento de Neurologia, Belo Horizonte, MG, Brazil.

${ }^{3}$ Universidade Federal de Minas Gerais, Hospital das Clínicas e Faculdade de Medicina, Serviço de Neurologia e Departamento de Clínica Médica Belo Horizonte, MG, Brazil.

Tatiana Vaz Leite PINTO (D) https://orcid.org/0000-0003-0057-0591; Antônio Pereira GOMES NETO (iD https://orcid.org/0000-0002-0755-9478;

Matheus Nader CUNHA (iD https://orcid.org/0000-0002-1290-7051; Letícia Moreira BERNARDINO (iD https://orcid.org/0000-0002-2304-2313;

Paulo Pereira CHRISTO (iD https://orcid.org/0000-0003-1224-5243

Correspondence:Tatiana Vaz Leite Pinto; Email: tatianavaz@hotmail.com.

Conflict of interest: There is no conflict of interest to declare.

Authors' contributions: TTVLP: conceptualization, formal analysis, investigation, methodology, project administration, software, writing-original draft; APGN: conceptualization, investigation, supervision, validation, writing-review \& editing; MNC: conceptualization, investigation, writing-review \& editing; LMN: conceptualization, investigation, writing-review \& editing; PPC: conceptualization, investigation, methodology, project administration, supervision, validation, writing-review \& editing.
}

Received on August 24, 2020; Received in its final form on October 21, 2020; Accepted on November 06, 2020. 


\section{INTRODUCTION}

Syphilis is a chronic bacterial infection caused by Treponema pallidum ${ }^{1}$. Ocular syphilis involves any structure of the eye and occurs at all stages of syphilis'. Given this varied presentation, syphilis has historically been known as "the great imitator" ${ }^{3}$. It can be included in the differential diagnoses of any form of ocular inflammation, uveitis and optic neuritis ${ }^{4}$. Prompt diagnosis and treatment prevent significant visual impairment, thus making its recognition a priority ${ }^{5}$.

In the pre-penicillin era, the incidence of syphilis was relatively high. After 1950, the incidence worldwide declined significantly as a consequence of widespread use of penicillin. In the 1980s, there was an increase in incidence, particularly among individuals co-infected with human immunodeficiency virus (HIV). However, it declined again in the 1990s. Syphilis has re-emerged since 2000, especially ocular syphilis. The Centers for Disease Control and Prevention issued a clinical advisory in 2015, and over 200 cases of ocular syphilis were reported in 20 American states over the following two years ${ }^{5}$. In Brazil, since 2010, notification following a diagnosis of syphilis has been required. The epidemiological bulletin of the health surveillance secretariat of the Brazilian Ministry of Health reported an increase in incidence over five years; the incidence of syphilis was 0.8 cases per 100,000 inhabitants in 2010 and increased to 42.7 per 100,000 inhabitants in $2015^{6}$. In 2018, the incidence increased further, reaching 75.8 per 100,000 inhabitants?

The objective of this study was to investigate the spectrum of manifestations of ocular syphilis and the factors that can lead to worse visual prognosis, in a clinical series of 53 patients.

\section{METHODS}

\section{Study design and data collection}

A prospective cohort was formed among patients within the public healthcare system who were admitted to our institution as ophthalmological emergencies between July 2014 and December 2016. These patients were subsequently diagnosed as presenting ocular syphilis at the Departments of Ophthalmology and Neurology of Santa Casa of Belo Horizonte, Brazil, a tertiary-level referral center in the State of Minas Gerais.

The inclusion criteria were that the patients should present the following: intraocular inflammation (optic neuritis or uveitis) and serological markers; positive treponemal tests (fluorescent treponemal antibody-absorbed, FTA-ABS; or Treponema pallidum hemagglutination assay, TPHA) and a positive non-treponemal investigation (venereal disease research laboratory, VDRL); or two positive treponemal tests. Patients were excluded when they presented a better alternative diagnosis for the ocular inflammation. The standard treatment was intravenous penicillin G, 4,000,000 IU every $4 \mathrm{~h}$ for 14 days, while the alternative regime was intravenous ceftriaxone, $1 \mathrm{~g}$ every $12 \mathrm{~h}$ for 14 days. The follow-up period continued until the patient achieved the cure criteria: non-reactive serum VDRL and normalized CSF. Medical appointments were scheduled at three months after treatment and then every six months.

Regarding syphilis stages, primary syphilis was characterized by a chancre at the inoculation site. Secondary syphilis was characterized as occurrences in cases of malaise, fever, rash, alopecia, lymphadenopathy, nephrotic syndrome, condylomata, mucous patches and meningitis. The latent form consisted of gumma, syphilitic aortitis, general paresis and tabes dorsalis. Patients without extraocular manifestation at the time of diagnosis were considered to be in the latent phase. If there was evidence of recent manifestation of the early stage of the disease (within one year), the case was considered to be early latent syphilis. If the manifestations occurred more than one year previously or at an unknown time, the case was considered to be late latent.

Regarding the characterization of uveitis, this was classified in accordance with the criteria of the Standardization of Uveitis Nomenclature working group 8 . In relation to gradation of visual acuity, the best-corrected visual acuity (BCVA) was converted to logarithm of the minimum angle of resolution $(\log \mathrm{MAR})$ to calculate the mean visual acuity and for statistical analysis9. Cerebrospinal fluid (CSF) was defined as abnormal when CSF-VDRL was positive; or CSF white blood cells $(\mathrm{WBC})>5$ cells $/ \mu \mathrm{L}$; or CFS protein $>45 \mathrm{mg} / \mathrm{dL}^{10}$. In HIV-infected patients, the criteria differed if peripheral blood CD4+ T cell $>200 / \mu \mathrm{L}$ or there was detectable plasma HIV RNA or no antiretroviral medications were being taken, such that CSF was defined as abnormal when there was reactive CFS-FTA-ABS and WBCs $>20 / \mu \mathrm{L}$. In HIV-infected patients with peripheral blood CD4+ T cells $<200 / \mu \mathrm{L}$ and undetectable plasma HIV RNA who were on antiretroviral therapy, the criterion was the same, i.e. CSF WBCs $>5 / \mu \mathrm{L}^{10}$.

Recrudescence or reinfection was considered to have occurred in the following situations: repeated episodes of ophthalmological signs and symptoms; failure of serum VDRL titers to decline fourfold in six months; or CSF abnormalities persisted, i.e. failure of CSF-WBC count to decrease six months after therapy, CSF-VDRL titers declined fourfold after one year or normalization of protein levels occurred over a two-year period ${ }^{10}$.

\section{Statistical analysis}

The data were analyzed using SPSS, version 20. The statistical significance was set at $p<0.05$. Continuous data variable distributions were tested for normality using the Kolmogorov-Smirnov test. The Student t test was applied to compare variables when the distribution was normal and the 
Mann-Whitney U, Kruskal-Wallis and Wilcoxon tests when the distribution was abnormal. Categorical variables were compered using the $\mathrm{X}^{2}$ or Fisher tests.

This study was approved by the Research Ethics Committee of Santa Casa Hospital of Belo Horizonte.

\section{RESULTS}

\section{Patient details}

Fifty-five cases of ocular syphilis were identified during the study period. Two cases were excluded due to concomitant diagnosis of other diseases that could also have impaired the patient's visual acuity. One was ocular toxoplasmosis and the other, inherited optic neuropathies. Fifty-three patients were included in the study. For comparative analysis 90 eyes were included. Four eyes were excluded from follow-up analysis due to lack of data. Twelve eyes had no visual impairment or signs of ocular inflammation.

The majority of the patients were male $(66.0 \%)$ with a mean age of 45.3 years (range 18-65 years). Ten patients were HIV-positive and seven of them were diagnosed with HIV at presentation. The demographic details and baseline clinical characteristics of the patients are described in Table 1.

\section{Clinical characteristics at presentation}

All the patients complained of decreased visual acuity at presentation. Sixteen $(30.2 \%)$ had ocular pain and seven $(13.2 \%)$ presented headaches. Bilateral ocular involvement was observed in $68.0 \%$ of patients. Nineteen patients (35.8\%) recalled previous symptoms consistent with primary syphilis infection (genital ulcers: 7 patients) or secondary syphilis (maculopapular rash: 11 patients). Five patients presented with widespread maculopapular rash and one had a nasal mucosal plaque.

The median baseline logMAR visual acuity was 1 (20/200 Snellen; range 0.2-2 logMAR). The mean interval between the onset of ocular symptoms and treatment was three weeks (range: 3 days to 36 weeks). Optic neuritis occurred in 51.7\% of the eyes; papillitis and optic nerve pallor were observed. Forty-two eyes $(48.2 \%)$ presented uveitis: anterior segment (2 eyes; 4.8\%), intermediate uveitis (3 eyes; $7.1 \%$ ) and, most frequently, posterior uveitis (27 eyes; 64.3\%). Panuveitis was identified in 10 eyes (23.8\%). Ocular lesions included vasculitis, observed in 10 patients (37.0\%) and 16 eyes; chorioretinitis in 6 patients $(22.2 \%)$ and 9 eyes; macular edema in 8 patients $(7.5 \%)$ and 11 eyes; and retinal hemorrhage in 2 patients $(11.1 \%)$ and 2 eyes.

\section{Laboratory profiles}

Serum VDRL titers were greater than or equal to $1: 32$ in $84.9 \%$ of the cases (range: non-reactive to 1:1024). Only one patient had non-reactive VDRL titers, but he presented
Table 1. Baseline epidemiological, clinical and laboratory characteristics of 53 patients.

\begin{tabular}{|c|c|}
\hline Continuous variables & Median (range) \\
\hline Age (years) & $45(18-65)$ \\
\hline $\begin{array}{l}\text { Duration of symptoms before } \\
\text { treatment (weeks) }\end{array}$ & $3(0.4-104)$ \\
\hline Follow-up (months) & $3(0.5-28)$ \\
\hline BCVA at presentation * & $1(0.2-2)$ \\
\hline BCVA at the end of follow-up * & $0.2(0-2)$ \\
\hline Categorical variables & $n(\%)$ \\
\hline Male sex & $35(66.0 \%)$ \\
\hline HIV-positive & $10(18.9 \%)$ \\
\hline Bilateral ocular syphilis & $36(68.0 \%)$ \\
\hline Serum VDRL $\bullet 1: 32$ & $45(84.9 \%)$ \\
\hline CSF abnormal & $39(73.6 \%)$ \\
\hline \multicolumn{2}{|l|}{ Syphilis stage } \\
\hline Primary & $0(0 \%)$ \\
\hline Secondary & $6(11.3 \%)$ \\
\hline Early latent & $5(9.4 \%)$ \\
\hline Late latent & $42(79.2 \%)$ \\
\hline \multicolumn{2}{|l|}{ Clinical Manifestation*\# } \\
\hline Optic neuritis & $45(51.7 \%)$ \\
\hline Uveitis & $42(48.2 \%)$ \\
\hline Anterior & 2 (4.8\% of uveitis) \\
\hline Intermediate & 3 (7.1\% of uveitis) \\
\hline Posterior & 27 (64.3\% of uveitis) \\
\hline Panuveitis & 10 (23.8\% of uveitis) \\
\hline \multicolumn{2}{|l|}{ Antibiotic therapy } \\
\hline Penicillin G & $12(22.6 \%)$ \\
\hline Ceftriaxone & $40(75.5 \%)$ \\
\hline Doxycycline & $1(1.9 \%)$ \\
\hline
\end{tabular}

BCVA: best-corrected visual acuity; LogMAR: logarithmic minimal angle resolution; VDRL: venereal disease research laboratory; CFS: cerebrospinal fluid.

*90 eyes were included; * one eye had a cataract and this classification was not applied to two eyes.

treponemal-positive titers for both FTA-ABS and TPHA and was CSF FTA-ABS-positive. VDRL titers were not correlated with the location of ocular inflammation $(p=0.8)$, HIV positivity $(\mathrm{p}=0.1$ ) or abnormal CSF ( $\mathrm{p}=0.7)$.

All the patients underwent lumbar puncture before treatment. Thirty-nine (73.6\%) showed abnormal CSF. VDRL in CSF was positive only in 13 patients $(24.5 \%)$. The mean CSF $\mathrm{WBC}$ count was $3 / \mathrm{mm}^{3}$ (range 1-189) and the mean protein level was $50 \mathrm{mg} / \mathrm{dL}$ (range 27-170).

\section{Treatment details}

Twelve patients $(22.6 \%)$ were treated with a recognized regimen of IV penicillin G, $40(75.5 \%)$ with IV ceftriaxone (due to unavailability of penicillin $\mathrm{G}$ ) and only one with 
doxycycline, due to an adverse cutaneous reaction with the other two drugs.

\section{Outcome}

The median follow-up among the patients was 3 months (range from 15 days to 28 months). Thirty-nine patients out of 53 had abnormal CSF and 19 presented controlled CSF. Of those, 18 showed a therapeutic response.

Improvement in BCVA was observed in all patients following treatment, in at least one eye. After antibiotic therapy, the median BCVA was 0.2 (20/30 Snellen; range 0-2 logMAR). Sixty-five eyes (72\%) were logMAR 0.3 (20/40 Snellen) or better. Poor visual acuity, of BCVA (logMAR) 1 (20/200 Snellen) or worse, showed statistically significance associations with the following: severe BCVA at presentation, of below logMAR 1.3 or $20 / 400$ Snellen $(p=0.001)$; age over 50 years $(p=0.001)$; and normal CSF $(p=0.006)$. However, it did not correlate with sex $(\mathrm{p}=0.2)$, HIV positivity $(\mathrm{p}=1.0)$, ocular manifestation $(\mathrm{p}$ $=0.8)$ or duration of symptoms before treatment $(p=0.2)$. The factors associated with worse prognosis after treatment are presented in Table 2.

Table 2. Factors significantly associated with BCVA (logMAR) at the end of follow-up (90 eyes).

\begin{tabular}{|c|c|c|c|}
\hline & $\begin{array}{l}\text { BCVA logMAR worse } \\
\text { than } 1 \text { (12 eyes) }\end{array}$ & $\begin{array}{l}\text { BCVA logMAR better } \\
\text { than } 1 \text { (78 eyes) }\end{array}$ & $\mathrm{p}$ \\
\hline \multicolumn{3}{|l|}{ Sex } & 0.1 \\
\hline Female & $2(16.7 \%)$ & $31(39.7 \%)$ & \\
\hline Male & $10(83.3 \%)$ & $47(60.3 \%)$ & \\
\hline \multicolumn{3}{|l|}{ Age } & 0.006 \\
\hline$<50$ years & $3(25.0 \%)$ & $53(67.9 \%)$ & \\
\hline$\geq 50$ years & $9(75.0 \%)$ & $25(32.1 \%)$ & \\
\hline \multicolumn{3}{|l|}{ CSF } & 0.006 \\
\hline Abnormal & $4(33.3 \%)$ & $59(75.9 \%)$ & \\
\hline Normal & $8(66.6 \%)$ & $19(24.3 \%)$ & \\
\hline \multicolumn{3}{|l|}{ BCVA at presentation } & 0.002 \\
\hline $20 / 25-20 / 40$ & $1(8.3 \%)$ & $20(25.6 \%)$ & \\
\hline $20 / 50-20 / 200$ & $1(8.3 \%)$ & $34(43.5 \%)$ & \\
\hline worse than $20 / 400$ & $10(83.3 \%)$ & $24(30.7 \%)$ & \\
\hline \multicolumn{3}{|l|}{ HIV } & 0.5 \\
\hline Positive & $3(25 \%)$ & $14(17.9 \%)$ & \\
\hline Negative & $9(75 \%)$ & $64(82.0 \%)$ & \\
\hline \multicolumn{3}{|l|}{ Treatment * } & 0.09 \\
\hline Penicillin G & 0 & $16(20.7 \%)$ & \\
\hline Ceftriaxone & $11(100 \%)$ & $61(79.2 \%)$ & \\
\hline \multicolumn{3}{|c|}{ Duration of symptoms before the treatment } & 0.5 \\
\hline$\leq 21$ days & $5(41.6 \%)$ & $40(51.2 \%)$ & \\
\hline$>21$ days & $7(58.3 \%)$ & $38(48.7 \%)$ & \\
\hline \multicolumn{3}{|l|}{ Clinical manifestation \# } & 0.2 \\
\hline Optic neuritis & $4(33.3 \%)$ & $41(53.9 \%)$ & \\
\hline Uveitis & $7(58.3 \%)$ & 35 (46.0\%) & \\
\hline
\end{tabular}

BCVA: best-corrected visual acuity; LogMAR: logarithmic minimal angle resolution; CSF: cerebrospinal fluid. * 2 doxycycline-treated eyes were excluded; \# one eye in the group "BCVA logMAR worse than 1" had cataracts and this classification was not applied to two eyes in the group "BCVA logMAR better than 1".

\section{DISCUSSION}

In this era of re-emergence of syphilis, ocular syphilis has gained the attention of a broad section of the healthcare community, because its prevalence has increased yearly and it can cause blindness and other disabilities. This disease constitutes $0.5 \%$ of syphilis cases and 4 to $6 \%$ of neurosyphilis cases and is a known public health problem. Our study confirmed that ocular syphilis is more common in men, which probably correlates with a disproportionate increase in syphilis among men who have sex with men ${ }^{1}$. The majority of the patients were diagnosed with HIV at presentation of ocular 
syphilis, which suggests that there is a larger number of HIVsyphilis coinfection cases at first presentation ${ }^{11}$. Syphilitic genital ulcers are densely infiltrated with lymphocytes (the primary target cells for HIV infection) and so provide an entry portal for HIV ${ }^{1}$.

Ocular syphilis can present in every stage of syphilis. A few patients of this series manifested or complained about systemic manifestations of syphilis. None of them were in the primary stage of syphilis. Evidence of systemic manifestation is not required for making the diagnosis, but it assists in the rational propaedeutics of systemic impairment.

In line with previous studies, the majority of the patients presented VDRL serum titers $\geq 1: 32^{12}$. One patient in our series was negative for the non-treponemal test, while two treponemal tests were positive (Fta-Abs and TPHA). A negative non-treponemal test in a symptomatic patient can be seen in early infection (before the development of detectable antibodies, or with the prozone phenomenon), or in individuals with untreated late syphilis who present a decline in non-treponemal antibody titers over time. This highlights the need for a high level of clinical suspicion and broader use of reverse algorithm screening, especially in low-prevalence populations ${ }^{1}$.

The majority of the patients showed bilateral involvement, and regarding uveitis, the posterior segment was most frequently involved ${ }^{13}$. The frequency of optic neuritis was greater than in other clinical series previously described. In the series presented by Northey et al., features suggestive of optic neuritis were only found in $27 \%$ of the 37 eyes evaluated ${ }^{13}$. In agreement with other studies, the clinical manifestation of ocular syphilis observed in the present study affected almost every eye structure and was nonspecific. Although posterior placoid chorioretinitis has been reported as a specific finding of ocular syphilis, it is rare and was not observed in our series. ${ }^{4}$

Worse prognosis was associated with greater severity of BCVA at presentation, age over 50 years and normal CSF ${ }^{12,14,15}$. It seems probable that older adults present more ocular comorbidity, chronic inflammation and worse capacity for cell regeneration. In line with previous studies, HIV status did not influence visual prognosis ${ }^{12,14}$. Longer duration of symptoms before treatment was not identified as poorer prognosis for visual acuity, as also predicted in previous series. Nor was there any relationship regarding sex and clinical manifestations (optic neuritis and uveitis) ${ }^{12}$. Worse prognosis was not associated with the antibiotic treatment. Our results corroborated a report of treatment of ocular syphilis with intravenous ceftriaxone ${ }^{16}$. Surprisingly, abnormal CSF predicted good ophthalmological recovery, thus indicating that the prognosis for subacute inflammation was better. Active inflammation responded to proper treatment, as already suggested by Balaskas et $\mathrm{al}^{16}$. Probably the breakdown of the blood-brain and blood-ocular barriers facilitated penetration of the antibiotic.

None of the patients with abnormal CSF showed additional neurological manifestations and a minority showed negative CSF-VDRL results. These findings suggest that ocular syphilis can present as a solitary manifestation of neurosyphilis without any other overt neurological impairment, and that abnormal CSF does not necessarily result in CSFVDRL positivity. Control lumbar puncture is recommended for $\mathrm{CDC}$, to evaluate treatment failure and prevent progression of the disease ${ }^{16}$. In addition, serum non-treponemal test monitoring, performed 3, 6 and 12 months after therapy is recommended and VDRL titers should decline fourfold by the sixth month ${ }^{17}$.

The incidence of ocular syphilis is a continuing threat. The roles of possible oculotropic strain and some specific genotype host toll-like receptors are unknown ${ }^{18,19}$. Awareness among healthcare professionals is needed, so that ocular syphilis is included in the differential diagnosis of ocular inflammation, with the aim of diagnosing it in its early stages.

This study had limitations. Patient follow-up was at irregular intervals, some patients had a short follow-ups, and there was a moderate degree of abstention. This was probably associated with the low socioeconomic level of the majority of the participants, the social stigma associated with this disease and the complete recovery of some patients, which discouraged them from continuing the follow-up. However, considering the low incidence of ocular syphilis, it is difficult to conduct prospective studies and it is important to accumulate data from such series of cases.

The main conclusions from this study are that the spectrum of ocular manifestations in syphilis is broad and that optic neuritis was the most common presentation of ocular syphilis in this clinical series. Patients with severe BCVA at presentation (below 20/400), age over 50 years and normal CSF showed an association with poor visual acuity after treatment.

\section{REFERENCES}

1. Hook EW. Syphilis. Lancet. 2017 Apr 15;389(10078):1550-7. https:// doi.org/10.1016/S0140-6736(16)32411-4

2. Northey LC, Skalicky SE, Gurbaxani A, McCluskey PJ. Syphilitic uveitis and optic neuritis in Sydney, Australia. Br J Ophthalmol. 2015 Sep;99(9):1215-9. https://doi.org/10.1136/ bjophthalmol-2014-306168

3. Shah BB, Lang AE. Acquired neurosyphilis presenting as movement disorders. Mov Disord. 2012 May;27(6):690-5. https://doi. org/10.1002/mds.24950

4. Davis JL. Ocular syphilis. Curr Opin Ophthalmol. 2014 Nov;25(6):5138. https://doi.org/10.1097/ICU.0000000000000099

5. Oliver SE, Aubin M, Atwell L, Matthias J, Cope A, Mobley V, et al. Ocular Syphilis - Eight Jurisdictions, United States, 2014-2015. MMWR Morb Mortal Wkly Rep. 2016 Nov 4;65(43):1185-8. 
6. Secretaria de Vigilância em Saúde. Boletim epidemiológico - Sífilis ano V. Brasil: Ministério da Saúde;2016. 29 p.

7. Secretaria de Vigilância em Saúde. Boletim epidemiológico - Sífilis ano V. Brasil: Ministério da Saúde; 2019.42 p.

8. Woolston SL, Dhanireddy S, Marrazzo J. Ocular syphilis: a clinical review. Curr Infect Dis Rep. 2016 Nov;18(11):36. https://doi. org/10.1007/s11908-016-0542-9

9. Messias A, Jorge R, Cruz AAV. [Logarithmic visual acuity charts: reasons to use and how to design it]. Arq Bras Oftalmol. 2010 May 6;73(1):96-100. https://doi.org/10.1590/S0004-27492010000100019

10. Ho EL, Tantalo LC, Jones T, Sahi SK, Marra CM. Point-of-care treponemal tests for neurosyphilis diagnosis. Sex Transm Dis. 2015 Jan;42(1):48-52. https://doi.org/10.1097/OLQ.0000000000000222

11. Lee SY, Cheng V, Rodger D, Rao N. Clinical and laboratory characteristics of ocular syphilis: a new face in the era of HIV coinfection. J Ophthalmic Inflamm Infect. 2015 Dec;5(1):56. https://doi. org/10.1186/s12348-015-0056-x

12. Tsuboi M, Nishijima T, Yashiro S, Teruya K, Kikuchi Y, Katai N, et al. Prognosis of ocular syphilis in patients infected with HIV in the antiretroviral therapy era. Sex Transm Infect. 2016 Dec;92(8):605-10. https://doi.org/10.1136/sextrans-2016-052568

13. Mathew RG, Goh BT, Westcott MC. British ocular syphilis study
(BOSS): 2-year national surveillance study of intraocular inflammation secondary to ocular syphilis. Invest Ophthalmol Vis Sci. 2014;55(8):5394-400. https://doi.org/10.1167/iovs.14-14559

14. Hoogewoud F, Frumholtz L, Loubet P, Charlier C, Blanche P, Lebeaux D, et al. Prognostic factors in syphilitic uveitis. Ophthalmology. 2017 Dec;124(12):1808-16. https://doi.org/10.1016/j.ophtha.2017.06.003

15. Zhang X, Du Q, Ma F, Lu Y, Wang M, LiX. Characteristics of syphilitic uveitis in northern China. BMC Ophthalmol. 2017 Jun 19;17(1):95. https://doi.org/10.1186/s12886-017-0491-6

16. Balaskas K, Sergentanis TN, Giulieri S, Guex-Crosier Y. Analysis of significant factors influencing visual acuity in ocular syphilis. $\mathrm{Br}$ J Ophthalmol. 2011 Nov;95(11):1568-72. https://doi.org/10.1136/ bjo.2010.194498

17. Marra CM. Neurosyphilis. Continuum (Minneap Minn). 2015 Dec;21(6):1714-28. https://doi.org/10.1212/CON.0000000000000250

18. Marra CM, Sahi SK, Tantalo LC, Ho EL, Dunaway SB, Jones T, et al. Toll-like receptor polymorphisms are associated with increased neurosyphilis risk. Sex Transm Dis. 2014 Jul;41(7):440-6. https://doi. org/10.1097/OLQ.0000000000000149

19. Oliver S, Sahi SK, Tantalo LC, Godornes C, Fanfair RN, Markowitz LE, et al. Molecular typing of treponema pallidum in Ocular Syphilis. Sex Transm Dis. 2016 Aug;43(8):524-7. https://doi.org/10.1097/ OLQ.0000000000000478 